\title{
Profile of Development of Critical Thinking Student Skills Assessment Instrument in the Course Geography of Disaster
}

\author{
*Erna Juita ${ }^{1)}$, Rahmi Zulva ${ }^{1)}$, and Helfia Edial ${ }^{2)}$
}

1) STKIP PGRI Sumatera Barat

2) Department of Geography, Universitas Negeri Padang-INDONESIA

Email: erna.pgri@gmail.com

*Corresponding Author, Received: January 15, 2018, Revised: March 02. 2018, Accepted: May 20, 2018

\begin{abstract}
In order to realize the goal of education, students are required to have critical thinking skills, especially in courses that are abstract like geography. Preliminary research has been done to find that the instruments used are not oriented to critical thinking skills. The purpose of this study is to know the process of developing critical thinking skills assessment instruments that meet the valid criteria. This type of research is development research by following the theory of device development according to Plomp (2013). The results show that the development of the device has been done only in the preliminary stage of research and prototyping phase. In the preliminary research stage the results obtained interviews with students and lecturers about the desired learning tool. At the phase prototyping phase obtained a good form of device to measure students' critical thinking skills.
\end{abstract}

Keywords: Critical Thinking, Student Skills, Geography Disaster

\section{Introduction}

Assessment of learning outcomes by educators conducted on an ongoing basis aims to monitor the process and progress of student learning and to improve the effectiveness of learning activities. Assessment of learning outcomes by lecturers is done to assess the achievement of student competence. The assessment instrument is an integral part of an assessment process in learning. Assessment serves as a process assessment program, learning progress, and student learning outcomes (Docktor and Heller, 2009; Hermon, 2012; Hermon, 2014; Hermon, 2017). Assessment instruments include tests and assessment systems. Assessment instruments are designed to determine the level of understanding of learners after studying a competency (Prasasti et.al., 2012; Oktorie, 2017). Achieving real geography learning objectives requires the use of assessment instruments that not only include memorization and comprehension but also judgments that practice thinking skills.

Assessment instrument designed properly and in accordance with the level of thinking skills can enhance students' thinking, especially critical thinking. Critical thinking skills are important to be trained because these thinking skills are not brought about by birth (Redhanadan Liliasari, 2008). The results of interviews with lecturers of geography at STKIP PGRI West Sumatra proved that the assessment instruments used still measure aspects of rote and understanding. Basic courses that can support these goals, one of them, is the course of Geography of Disaster. Objectives to be achieved after students study the Geography of Disasters (Hermon, 2009; Hermon, 2014), are: (1) the design of scientific thinking that is critical, logical, and systematic, (2) trained the power of reason and creativity after learning the various strategies and tactics in solving the problems of disasters that occur, (3) trained in designing simple Geography tools, on disaster problem emphasis, and (4) skilled in technical Geography standard with the supported concepts, reasoning, formulas, and the correct method. 
After this goal is achieved, students are expected to more easily study Geography in other courses based on Disaster Geography as a tool. Disaster geography is a course that not only requires memorization and understanding, but also requires high analysis. Based on this, research on the development of students' critical thinking skills assessment instrument in disaster geography courses was conducted. The assessment instrument developed in this study is an assessment instrument that can measure students' critical thinking skills. This assessment instrument is designed to improve students' thinking skills. Student thinking skills can be seen from the level of assessment instruments tested and the proportion of mastery. In addition, the critical thinking skills assessment instrument in the geography course of disaster is presented by lifting the phenomenon that occurs in everyday life. The objectives of the research are 1) to know the process of developing the critical thinking skills assessment instrument, 2) to obtain innovation of new critical thinking skill assessment instrument that can measure students 'critical thinking skill, and 3) to obtain the critical thinking skill assessment instrument that can measure students' critical thinking skill that meets the valid criteria.

\section{Method}

In this research follow the theory of device development according to plomp $(2013 ; 19)$ which consist of phase that is preliminary research, prototyping phase, and assessment phase. Each phase is described in Table 1.

Table 1. Evaluation Criteria at Each Stage of Development

\begin{tabular}{lll}
\hline \multicolumn{1}{c}{ Phase } & \multicolumn{1}{c}{ Criteria } & \multicolumn{1}{c}{ Activity Description } \\
\hline $\begin{array}{l}\text { Preliminary Research } \\
\text { Prototyping Phase }\end{array}$ & $\begin{array}{l}\text { Emphasis on Content Validity } \\
\text { Focus On Consistency (Construct Validity) and } \\
\text { Practicality. Next Prioritize Practicality and } \\
\text { Gradually Towards Efficiency } \\
\text { Practicality and Efficiency }\end{array}$ & $\begin{array}{l}\text { Problem Analysis and Literature Study } \\
\text { Development of prototypes to be tested and revised } \\
\text { based on formative evaluation }\end{array}$ \\
& & $\begin{array}{l}\text { Assessing Whether Users Can Use the Product } \\
\text { (Practicality) and Desiring to Apply It is Also } \\
\text { Effective }\end{array}$ \\
\hline
\end{tabular}

\section{Results and Discussion}

In this study, only reached the stage of prototyping phase. Formative evaluation takes place in all phases and development iteration cycles. As illustrated in Table 1, formative evaluation has different functions in each development cycle. Initial stage, the evaluation is focused on the content validity. At the prototyping stage, the evaluation focuses on the relevance (content validity) of consistency (construct validity) and practicality. The next stage focuses on practicality and effectiveness when the product is tested. According to Tessmer (1993) in Plomp (2013) formative evaluation has several layers as follows: (1) Expert review: expert group (subject matter expert, design learning expert) provides assessment and suggestions on developed products, (2) Self-evaluation: using checklists of important characteristics or design specifications, (3) Oneon-one evaluation: with a representative user, (4) Small group or micro-evaluation: a small group of users using the product in a situation that is the norm. Evaluators observe and interview respondents, and (5) Field test: a group of users using the product in actual conditions to measure the effectiveness and effectiveness of the product.

The details of the development procedure include the following steps:

\section{Preliminary Research}

At this stage, problem identification and data collection for the design of assessment tools are provided, among others, (a) the types of assessments applied and their implementation procedures in Disaster Geography lectures, (b) student expectations of assessment tools implemented in Disaster Geography, (c) involvement of lecturers and students in the implementation of assessment in Disaster Geography learning. (d) certain skills and competencies required in Disaster Geography lectures. Data collection was conducted through interviews with the team of lecturers of Disaster Geography lecturers and students who attended 
Disaster Geography lectures, syllabus document collection, lecture plan and student work result. Interview data were analyzed descriptively qualitative.

\section{Prototyping Phase}

Based on the results of initial investigation conducted preparation of assessment tools. Formative evaluation is instrumental in the prototyping stage.

\section{Asesment Phase}

At this stage, an experimental prototype test was conducted on the students of Geography Study Program at STKIP-PGRI West Sumatra. Evaluation is done at each stage of the trial. Evaluation results are used to revise the assessment draft.

The instrument used in this research is critical thinking test. The critical thinking test is created and analyzed by the expert, so that the validity of an instrument is obtained. Validation results on all aspects observed, presented in table form then searched average. Average confirmed by criteria: Very Valid if 3.20 $<$ average $\leq 4.00$; Valid if $2.40<$ average $\leq 3.20$; Quite valid if $1.6<$ average $\leq 2.40$; Less valid if $0.80<$ mean $\leq$ 1.60; and Invalid if the mean $\leq 0.80$ (Modified from Arikunto, 2010).

In the preliminary research stage, the initial investment stage has been completed, which identifying problems and collecting data for the design of assessment models, among others, (a) the types of assessment implemented and the implementation procedures in the Geography Disaster lecture, (b) the students' expectation of the assessment model applied in disaster geography learning, (c) lecturer and student involvement in assessment implementation in disaster geography learning. (d) certain skills and competencies required in disaster geography lectures. In the prototyping phase of research has been up to the preparation of prototype, self-evaluation, and revise.

The results of interviews with students and lecturers, observation and review of lecture documents are conducted to obtain data on the types of assessment, advantages and disadvantages of assessment, the types of assessment desired, the views of lecturers / students who can touch three domains, and the views of lecturers / students on assessments that can develop students' critical thinking skills. Each of the results on these aspects is as follows:

a. Type of Assessment. Type of assessment used Activity and attitude observation sheet, Written Test (Quiz and Trial), but the observation sheet has not been recorded properly. The assessments used so far are not good enough to measure the students' critical thinking level. Critical thinking ability is measured but still very weak, need to prepare the right instrument instrument.

b. The advantages and disadvantages of the assessment. The advantages of the assessment used so far are that the lecturer can observe in detail for each individual, and the indicators can be seen (read, write etc.), but to observe intensively the observer is required other than the lecturer. In addition, the lecturer stated that the assessment aspect of the instrument still requires improvement and development.

c. Type of assessment desired. Lecturers expect a device that can assess the level of students' critical thinking skills. While the students expect the lecturer to give an assessment not only through the exam results and tasks but also observe things related to attitudes and skills.

d. Lecturers 'opinion on the assessment that can measure the students' critical thinking level, the observation of the activity should have a contribution to the final value.

e. Lecturer / student's view of the assessment that can develop students' critical geography thinking ability is still low. Therefore, appropriate and well-measured assessments are required.

Based on the results of initial investigation carried out the preparation of critical thinking assessment tools. This assessment has passed the evaluation by the researchers themselves (self evaluation) and is ready to be validated (Expert review). Critical thinking accesses have been designed for Disaster Mitigation material. The assessment consists of five parts: 1) Hazards, 2) Risks, 3) Vulnerability, 4) Potential, disaster 5) Disaster Management. The design of the assessment is adjusted and takes into account the Learning Outcome from Geography of Disasters. The design of this critical thinking assessment only takes six critical thinking indicators: 1) Identifying assumptions, 2) formulating the issues, 3) determining the consequences of a provision taken, 4) detecting bias, 5) revealing data / concepts / definitions / theorems in solving the problem, and 6) evaluating the relevant arguments in solving the problem. 


\section{Conclusion}

Critical thinking assessments are designed on the lattice. The assessment is completed with a scoring and assessment rubric. Grid developed based on material, Learning Achievement and indicators. While the rubric developed on 4 levels are: Very Critical (3), Critical (2), Self Critical (1), and Not Critical (0). Instruments used to assess critical thinking skills and problem solving should be guided by basic knowledge. In solving the problem of thinking process is more important than the knowledge possessed, even so basic knowledge is also a factor that is not less important in solving a problem (Carson, 2007). Therefore, the development of critical thinking skills instruments is done without overriding the concept.

\section{References}

Arikunto, S. (2010). Manajemen Penelitian. Jakarta: Rineka Cipta

Carson, J., (2007). A Problem With Problem Solving: Teaching Thinking Without Teaching Knowledge, The Mathematics Educator. Vol 17. No 2. Hal: 7-14.

Docktor, J. dan Heller, K., (2009). Robust Assessment Instrument for Student Problem Solving. Prosiding the NARST 2009 Annual Meeting, Minnesota University.

Hassoubah, Zaleihazhab. (2004). Developing Creatif \& Critical Thingking Skill. Terjemahan Bambang Suriadi. Bandung: Nuansa

Hermon, D. (2009). Dinamika Permukiman dan Arahan Kebijakan Pengembangan Permukiman pada Kawasan Longsor di Kota Padang. Disertasi. IPB Bogor

Hermon, D. (2012). Mitigasi Bencana Hidrometeorologi: Banjir, Longsor, Degradasi Lahan, Ekologi, Kekeringan, dan Puting Beliung. UNP Press.

Hermon, D. (2014). Geografi Bencana Alam. Radjawali Press.

Hermon, D. (2017). Climate Change Mitigation. Rajawali Pers (Radjagrafindo). Jakarta.

Oktorie, O. (2017). A Study of Landslide Areas Mitigation and Adaptation in Palupuah Subdistrict, Agam Regency, West Sumatra Province, Indonesia. Sumatra Journal of Disaster, Geography and Geography Education. Vol. 1. No. 1: 43-49

Plomp, T. (2013). Educational Design Research an Introduction, dalam Tjeerd Plomp dan Nienke Nieveen (Eds), Educational Design Research Part A. Enschede:slo

Prasasti, Y. R., Suyono dan Basuki, I. A., (2012). Pengembangan Instrumen Asesment Berpikir Kritis melalui Membaca untuk Siswa SD/MI. Jurnal Universitas Negeri Malang. Vol. 48, No 2, hal:1-12.

Redhana, I. W. dan Liliasari. (2008). Program Pembelajaran Keterampilan Berpikir Kritis pada Topik Laju Reaksi untuk Siswa SMA. Jurnal Forum Kependidikan. Vol 27. No 2. Hal:103-112. 